\title{
HUBUNGAN STATUS GIZI DENGAN PERKEMBANGAN MOTORIK KASAR ANAK UMUR 1-3 TAHUN DI POSYANDU BUNGA CENGKEH DESA PUNCAK HARAPAN KECAMATAN MAIWA
}

\section{The Relationship Of Nutrient Status To The Develompment Of Childs Motorist In The Age Of 1-3 Years In Posyandu Bunga Cengkeh Desa Puncak Harapan Kecamatan Maiwa}

\author{
Ratna Suhartini ${ }^{1}$, Haniarti ${ }^{2}$, Makhrajani Majid ${ }^{3}$ \\ ${ }^{1}$ Mahasiswa Konsentrasi Gizi Fakultas Ilmu Kesehatan Universitas Muhammadiyah Parepare \\ ${ }^{2}$ Dosen Program Studi Kesehatan Masyarakat Universitas Muhammadiyah Parepare \\ ${ }^{3}$ Dosen Program Studi Kesehatan Masyarakat Universitas Muhammadiyah Parepare
}

(ratnasuhartini95@gmail.com)

\begin{abstract}
ABSTRAK
Masalah kurang gizi selain disebabkan oleh berkurangnya jumlah konsumsi karena melemahnya daya beli masyarakat dan mutu gizi yang rendah juga disebabkan oleh masih banyaknya warga masyarakat yang kurang memiliki pengetahuan tentang pentinganya pemenuhan gizi sejak masa balita. Hal ini akan berdampak pada perkembangan balita yang kurang optimal. Penelitian ini bertujuan untuk mengetahui hubungan status gizi dengan perkembangan motorik kasar anak umur 1-3 tahun di posyandu Bunga Cengkeh desa Puncak Harapan. Jenis penelitian ini yaitu deskriptif analitik dengan pendekatan cross sectional study. Populasi dalam penelitian ini adalah anak umur 1-3 tahun. Teknik pengambilan sampel dilakukan secara total sampling, sampel dalam penelitian ini sebanyak 33 orang. Analisis data dengan menggunakan uji chi square. $\mathrm{H}_{0}$ ditolak jika nilai $p>0,05$. Hasil penelitian diperoleh ada hubungan status gizi dengan perkembangan motorik kasar anak umur 1-3 tahun di posyandu Bunga Cengkeh desa Puncak Harapan $(p=0,04)$. Disarankan agar orang tua dapat tetap memperhatikan asupan nutrisi untuk memperbaiki status gizi batita sehingga perkembangan motoriknya akan sesuai dengan umur meskipun sudah beranjak ke tingkatan umur berikutnya karena salah satu faktor yang mempengaruhi perkembangan motorik kasar adalah status gizi anak. Pihak kader posyandu disarankan memberikan pemahaman mengenai pentingnya status gizi batita dan mendampingi orang tua batita saat dilakukan penyuluhan oleh pihak puskesmas setempat.
\end{abstract}

\section{Kata Kunci : Status Gizi, Perkembangan Motorik Kasar, Anak Umur 1-3 tahun}

\begin{abstract}
The problem of lack of nutrient was not only caused by diminishing consume health food because the low of the society income but also caused by the lack of knowledge about the importance of nutrient fulfillment in the early age. Its causing the child development is not optimal. This research aims to know the relationship between the nutrient status and the childs development motorist in the age of 1-3 years in posyandu Bunga Cengkeh desa Puncak Harapan Kecamatan Maiwa. The research applien analytic research with cross sectional study approach. The populations of this research were childs in the age of 1-3 years. The sample was taken by total sampling technique. Sample of this
\end{abstract}


research consisted of 33 sample. The data analysis was done by using chi square. It showed that $H_{0}$ was rejected in the score of $p<0,05$. The result of this research that taken by the relationship of nutrient status to the development childs motorist in the age of 1-3 yearsin posyandu Bunga Cengkeh Desa Puncak Harapan was $p=0,04$. From the research its suggested to the parents to pay attention on the childs sufficiency nutrient improve the childs nutrient status so their motorist development will appropriate to their ages even though get older because it can influence the child motorist developments. Then the employee of posyandu is suggested to give a good comprehension about the importance of childs nutrient status and accompany the parents the posyandu conducting elucidation in the certain local clinic.

Keywords : Nutritional status, gross motor, children from 1-3 year

\section{PENDAHULUAN}

Kesehatan adalah hak asasi manusia dan sekaligus merupakan investasi sumber daya manusia, sekaligus memiliki kontribusi yang besar untuk meningkatkan Indeks Pembangunan Manusia (IPM). Dalam Sistem Kesehatan Nasional (SKN) tahun 2009 sebagai penyempurnaan dari SKN sebelumnya merupakan bentuk dan cara penyelenggaraan pembangunan kesehatan yang dilakukan oleh pemerintah dan bersama seluruh elemen bangsa dalam rangka untuk meningkatkan tercapainya pembangunan kesehatan dalam mewujudkan derajat kesehatan yang setinggitingginya. ${ }^{1}$

Tujuan utama pembangunan nasional adalah peningkatan kualitas Sumber Daya Manusia (SDM) yang dilakukan secara berkelanjutan. Upaya peningkatan kualitas sumber daya manusia ini dimulai dengan pemenuhan kebutuhan sumber daya manusia dan hal ini akan tercapai jika pemenuhan kebutuhan ini dimulai sedini mungkin, perhatian utamanya terletak pada proses tumbuh kembang anak sejak pembuahan sampai mencapai dewasa muda. Pemenuhan kebutuhan sejak dini merupakan pondasi dan titik awal untuk meningkatkan kualitas sumber daya manusia. Jika kita membicarakan pemenuhan kebutuhan sumber daya manusia sejak dini maka jelas target pada fase ini adalah bayi dan balita, dan pada fase ini titik terpentingnya adalah pertumbuhan fisik kemudian diikuti perkembangan psikisnya.

Tumbuh kembang dikatakan terlambat jika seorang anak tidak mencapai tahap pertumbuhan dan perkembangan yang diharapkan pada umur yang semestinya, dengan ketertinggalan dalam populasi yang normal. Prevalensi keterlambatan di suatu populasi sangat bervariasi, studi yang dilakukan Dudley mencatat 3,3\%-17\% anak mengalami keterlambatan. ${ }^{2}$

Maryanti (2011) menegaskan bahwa periode penting dalam tumbuh kembang anak adalah masa balita. Tahap perkembangan anak 
terdapat masa kritis, dimana diperlukan rangsangan/stimulus yang tepat agar potensi yang ada pada anak berkembang secara optimal, sehingga pada masa perkembangan ini perlu mendapat perhatian terutama dari orang tua. ${ }^{3}$

Hasil penelitian perkembangan motorik pada anak dibawah umur lima tahun mengemukakan kelambatan perkembangan motorik sebanyak $49 \%$, akibat pengetahuan ibu kurang baik dan terjadi di negara berkembang. Keterlambatan perkembangan motorik sebanyak 50\% di Asia, di Afrika sebanyak $30 \%$, dan $20 \%$ terjadi pada anak-anak di Amerika Latin. ${ }^{4}$

Masalah kurang gizi selain disebabkan oleh berkurangnya jumlah konsumsi karena melemahnya daya beli masyarakat dan mutu gizi yang rendah juga disebabkan oleh masih banyaknya warga masyarakat yang kurang memiliki pengetahuan tentang pentinganya pemenuhan gizi sejak masa balita. Masyarakat belum aktif terlibat dalam program pangan dan gizi menjadi rendah. Hal ini akan berdampak pada perkembangan balita yang kurang optimal. $^{5}$

Secara nasional, prevalensi berat-kurang pada tahun 2013 adalah 19,6 persen, terdiri dari 5,7 persen gizi buruk dan 13,9 persen gizi kurang. Jika dibandingkan dengan angka prevalensi nasional tahun $2007(18,4 \%)$ dan tahun $2010(17,9 \%)$ terlihat meningkat. Perubahan terutama pada prevalensi gizi buruk yaitu dari 5,4 persen tahun 2007, 4,9 persen pada tahun 2010, dan 5,7 persen tahun 2013. Sedangkan prevalensi gizi kurang naik sebesar 0,9 persen dari 2007 dan 2013. Untuk mencapai sasaran MDG tahun 2015 yaitu 15,5 persen maka prevalensi gizi buruk-kurang secara nasional harus diturunkan sebesar 4.1 persen dalam periode 2013 sampai $2015{ }^{6}$

Hasil penelitian terdahulu yang dilakukan oleh Maryuni (2014) di Kelurahan Duren Sawit Jakarta Timur dan Desa Rumpit Bogor Jawa Barat pada anak usia 3-5 tahun menunjukkan semakin besar usia anak cenderung semakin menyimpang atau meragukan perkembangan motoriknya. Penyimpangan perkembangan motorik kasar pada anak usia 3 tahun sebesar 1,4\%, penyimpangan perkembangan motorik kasar pada anak usia 4 tahun sebesar 1,2\%, dan penyimpangan perkembangan motorik kasar anak usia 5 tahun sebesar 2,5\%. Dengan status gizi sangat pendek sebesar 3,9\%, pendek $15,1 \%$, normal $79,1 \%$, dan tinggi $2,0 \% .^{7}$

Enrekang merupakan sebuah Kabupaten yang berada di Sulawesi Selatan. Enrekang terdiri dari beberapa kecamatan dan desa salah satunya adalah desa Puncak Harapan. Desa Puncak Harapan berada dalam wilayah kerja Puskesmas Maiwa. Berdasarkan hasil Pemantauan Status Gizi (PSG) Puskesmas Maiwa tahun 2017 prevalensi gizi kurang, sangat pendek dan pendek, terdapat 8 orang atau sebanyak 9,3\% balita dengan gizi kurang, 
3 orang atau sebanyak 3,5\% sangat pendek dan 7 orang atau sebanyak $8,1 \%$ pendek. $^{8}$

Berdasarkan uraian latar belakang tersebut, maka peneliti bermaksud melakukan penelitian tentang "Hubungan Status Gizi dengan Perkembangan Motorik Kasar Anak Umur 1-3 tahun di Posyandu Bunga cengkeh desa Puncak Harapan”.

Tujuan penelitian ini adalah untuk mengetahui hubungan status gizi dengan perkembangan motorik kasar anak umur 1-3 tahun di posyandu bunga cengkeh desa Puncak Harapan Kecamatan Maiwa.

\section{BAHAN DAN METODE}

Desain penelitian ini menggunakan metode penelitian deskriptif analitik dengan pendekatan cross sectional. Populasi dalam penelitian ini sebanyak 30 orang. Penelitian ini menggunakan total sampling. Variabel independen dalam penelitian ini adalah status gizi sedangkan variabel dependennya adalah perkembangan motorik kasar anak umur 1-3 tahun. Data primer diperoleh dari hasil pengukuran tinggi badan, penimbangan berat badan serta wawancara langsung dengan orang tua anak menggunakan media kuesioner. Data sekunder diperoleh melalui hasil Pemantauan Status Gizi (PSG) Puskesmas Maiwa dan Kohort Balita Pustu Puncak Harapan. Data yang sudah diolah, diuji dengan uji Chi Square nilai signifikan (nila $p$ ), jika nilai $p<0,05$ maka $\mathrm{H}_{0}$ ditolak sehingga ada hubungan status gizi dengan perkembangan motorik kasar anak umur 1-3 tahun di posyandu Bunga Cengkeh desa Puncak Harapan kecamatan Maiwa.

\section{HASIL}

Karakteristik ibu berdasarkan tingkat pendidikan pada Tabel 1 menunjukkan bahwa dari 33 orang responden tertinggi terdapat pada tingkat SMP yaitu 14 orang atau $(63,6 \%)$ sedangkan tingkat pendidikan terendah terdapat pada tingkat Sarjana sebanyak 5 orang atau $(15,2 \%)$. Karakteristik ibu dari 33 orang responden berdasarkan pekerjaan, kategori pekerjaan tertinggi yaitu IRT sebanyak 29 orang atau $(87,9 \%)$, sedangkan yang terendah erdapat pada kategori Petani dan Honorer yang masing-masing sebanyak 2 orang atau $(6,1 \%)$. Karakterisrik ibu responden berdasarkan umur, umur ibu yang tertinggi yaitu 27-31 tahun sebanyak 18 orang atau $(54,5 \%)$, sedangkan yang terendah yaitu umur 32-36 tahun sebanyak 3 orang atau $(9,1 \%)$,

Karakteristik responden berdasarkan jenis kelamin pada Tabel 2 menunjukkan bahwa jenis kelamin dari 33 orang responden tertinggi terdapat pada kategori jenis kelamin perempuan yaitu 18 orang atau (54,5\%) sedangkan kategori jenis kelamin laki-laki sebanyak 15 orang atau $(45,5 \%)$. Karakteristik responden berdasarkan umur, jumlah responden berdasarkan tingkat umur, kelompok umur 1 tahun sebanyak 10 orang atau (30,3\%), kelompok umur 2 tahun sebanyak 20 orang 
atau $(60,6 \%)$ dan kelompok umur 3 tahun yaitu 3 orang atau $(9,1 \%)$. Karakterisrik responden berdasarkan jumlah saudara di Posyandu Bunga Cengkeh Desa Puncak Harapan, kategori jumlah saudara 1 orang sebanyak 10 orang atau (30,3\%), jumlah saudara 2 orang sebanyak 12 orang atau (36,4\%), jumlah saudara 3 orang sebanyak 8 orang atau $(24,2 \%)$, jumlah saudara 5 orang sebanyak 2 orang atau $(6,1 \%)$, sedangkan jumlah saudara 7 orang sebanyak 1 orang atau $(3,0 \%)$.

Jumlah responden berdasarkan status gizi pada Tabel 3 menunjukkan bahwa dari 33 orang responden, jumlah responden berdasarkan status gizi yang terbesar terdapat pada kategori status gizi normal sebanyak 26 orang atau $(78,8 \%)$ sedangkan yang terkecil terdapat pada kategori status gizi kurang sebanyak 7 orang atau (21,2\%). Status gizi responden ditentukan melalui perhitungan antropometri dengan menggunakan aplikasi WHO Antro. Terdapat 4 kategori status gizi sesuai ambang batas (Z-Score) menurut Depkes RI yaitu status gizi buruk (<-3 SD), status gizi kurang (-3 SD s/d <-2 SD), gizi baik (-2 SD s/d 2 SD), dan status gizi lebih ( >2 $\mathrm{SD})$.

Jumlah responden berdasarkan perkembangan motorik kasar pada Tabel 4 menunjukkan bahwa dari 33 orang responden yang terbesar terdapat pada kategori sesuai sebanyak 31 orang $(93,9 \%)$ sedangkan yang terkecil terdapat pada kategori tidak sesuai sebanyak 2 orang $(6,1 \%)$.

Perkembangan motorik sesuai lebih banyak pada status gizi normal sebesar 26 orang dengan persentase $100 \%$ berdasarkan Tabel 5 dibanding dengan perkembangan motorik yang sesuai dengan status gizi kurang sebanyak $71,4 \%$. Sedangkan untuk kategori perkembangan motorik tidak sesuai lebih besar pada status gizi kurang yaitu 2 orang dengan persentase $6,1 \%$. Berdasarkan analisis chi square diperoleh nilai $p=0,04<\alpha=0,05$ maka Ha diterima dan H0 ditolak, sehingga hasil tersebut menunjukkan bahwa ada hubungan status gizi dengan perkembangan motorik kasar.

\section{PEMBAHASAN}

Hasil penelitian menunjukkan bahwa tingkat pendidikan orang tua responden dilihat dari tingkat pendidikan ayah dan ibu, dimana tingkat pendidikan ayah yang tertinggi yaitu SMP sebanyak 14 orang dengan persentase $42,4 \%$ sedangkan yang terendah yaitu Sarjana sebanyak 5 orang dengan persentase 15,2\%. Untuk pendidikan ibu yang tertinggi terdapat pada tingkat SD dan SMP sebanyak 11 orang dengan persentase $33,3 \%$. Tingkat pendidikan orang tua hanya sampai pada tingkat SMP karena adanya beberapa faktor, seperti jarak tempat tinggal ke sekolah dan faktor biaya. Tingkat pendidikan ibu yang hanya sampai pada tingkat SMP termasuk kategori rendah (Undang-Undang No.20 Tahun 2003), 
sehingga akan mempengaruhi pola asuh dan perhatian terhadap status gizi dan perkembangan motorik kasar batita. ${ }^{9}$

Hasil penelitian menunjukkan pekerjaan ibu yang paling tinggi yaitu sebagai IRT sebanyak 29 orang atau (87,9\%), sedangkan rendah yaitu honorer dan petani yang masing-masing 2 orang atau $(6,1 \%)$. Hal ini disebabkan oleh beberapa faktor seperti tingkat pendidikan ibu yang hanya sampai pada tingkat SMP sehingga sulit dalam mencari pekerjaan, sehingga lebih memilih untuk mengurus anak dan menyelesaikan pekerjaan rumah. Penelitian menunjukkan bahwa umur ibu yang paling tinggi yaitu umur 27-31 tahun sebanyak 18 orang atau (54,5\%), sedangkan yang terendah yaitu umur 32-36 tahun sebanyak 3 orang atau $(9,1 \%)$. Wanita pada kelompok umur ini telah memiliki kematangan reproduksi, emosional, maupun aspek sosial yang memungkinkan untuk merawat dan mengasuh batita.

Hasil penelitian menunjukkan responden berdasarkan dengan jenis kelamin yang paling banyak mengikuti posyandu di Posyandu Bunga Cengkeh yaitu jenis kelamin perempuan sebanyak 18 orang dengan persentase $54,5 \%$ sedangkan yang terkecil yaitu jenis kelamin laki-laki sebanyak 15 orang dengan persentase $45,5 \%$. Hasil tersebut berdasarkan data yang diperoleh dari Kohort Balita di Pustu desa Puncak Harapan dengan proporsi batita perempuan lebih banyak dibandingkan batita laki-laki.

Terlihat pula bahwa responden berdasarkan umur yang paling banyak terdapat pada umur 2 tahun sebanyak 20 orang dengan persentase $60,6 \%$ sedangkan paling rendah pada umur 3 tahun sebanyak 3 orang dengan persentase $9,1 \%$. Hasil penelitian tersebut dikarenakan pada saat dilakukan penelitian, umur batita sudah banyak yang memasuki umur 2 tahun. Umur ini merupakan kelompok umur yang sangat memerlukan perhatian khusus karena kelompok umur ini merupakan golden periode yang sangat membutuhkan asupan nutrisi yang cukup untuk pembentukan tumbuh kembang.

Hasil penelitian menunjukkan bahwa jumlah anak (saudara) yang tertinggi yaitu 2 orang dengan persentase $36,4 \%$ sedangkan yang terendah yaitu 7 orang dengan persentase $3,0 \%$. Hasil tersebut berdasarkan wawancara dengan responden yang mempunyai 2 orang anak karena mengikuti program Keluarga Berencana (KB). Selain itu, jumlah saudara dan jarak kelahiran juga sangat mempengaruhi tumbuh kembang anak, karena pola asuh ibu akan terbagi kepada anak-anaknya.

Status gizi responden paling banyak terdapat pada kategori status gizi normal sebanyak 26 orang dengan persentase $78,8 \%$ sedangkan yang terendah terdapat pada kategori kurang yaitu 21,2\%. Hal tersebut disebabkan karena asupan nutrisi yang diterima 
batita sudah sesuai dengan kebutuhan nutrisinya. Status gizi akan mempengaruhi perkembangan motorik kasar batita. Perkembangan motorik kasar paling banyak terdapat pada kategori sesuai sebanyak 31 orang dengan pesentase $93,9 \%$ sedangkan yang terendah terdapat pada kategori tidak sesuai sebanyak 2 orang dengan persentase $6,1 \%$. Hal ini karena semakin bangus status gizi responden akan mempengaruhi perkembangan motorik kasar batita.

Status gizi merupakan keadaan tubuh sebagai akibat interaksi antara semua asupan energi dan protein serta zat-zat gizi esensial lainnya dengan kesehatan tubuh. Sehingga seringkali status gizi mempengaruhi pertumbuhan dan perkembangan anak.

Motorik kasar adalah kemampuan gerakan-gerakan tubuh yang membutuhkan koordinasi tubuh dengan melibatkan otot-otot besar dalam melakukan aktivitas fisik sehingga membutuhkan tenaga yang besar. Menurut Soetjiningsih (1995), Sutrisno YM (2014) faktor yang mempengaruhi perkembangan motorik kasar anak digolongkan atas faktor herediter, faktor hormonal dan faktor lingkungan. Faktor lingkungan antara lain faktor status gizi, pola asuh, cuaca, dan status kesehatan. $^{(1)}$

Pada penelitian yang telah dilakukan, responden penelitian adalah anak umur 1-3 tahun yang merupakan masa-masa awal perkembangan anak, inilah yang disebut dengan golden periode. Hal tersebut sesuai dengan pentingnya pembentukan tumbuh kembang anak pada 2 tahun pertama kehidupan. Pada masa ini pemenuhan nutrisi yang diterima akan memiliki dampak jangka panjang terhadap kehidupan saat usia dewasa. Penentuan status gizi pada penelitian ini menggunakan indikator Berat Badan menurut Umur $(\mathrm{BB} / \mathrm{U})$, dengan hasil penelitian batita dengan status gizi normal sebanyak 26 orang $(78,8 \%)$ sedangkan status gizi kurang sebanyak 7 orang $(21,2 \%)$. Tabel 4 menjelaskan tentang status gizi anak umur 1-3 tahun di posyandu Bunga Cengkeh desa Puncak Harapan menunjukkan bahwa lebih banyak yang berstatus gizi normal.

$$
\text { Selanjutnya hasil mengenai }
$$
perkembangan motorik kasar anak dapat dilihat bahwa $93,9 \%$ perkembangan sesuai dan $6,1 \%$ perkembangan tidak sesuai. Tabel 4 menjelaskan tentang perkembangan motorik kasar anak umur 1-3 tahun dengan hasil menunjukkan bahwa lebih banyak perkembangan motorik yang sesuai. Jika keduan variabel dihubungkan diperoleh hasil bahwa ada hubungan antara status gizi dengan perkembangan motorik kasar anak.

Pada penelitian ini ada hubungan antara status gizi dengan perkembangan motorik kasar, terlihat bahwa status gizi normal lebih banyak terdapat pada perkembangan motorik yang sesuai (100\%) sedangkan status gizi kurang lebih banyak terdapat pada 
perkembangan motorik yang tidak sesuai $(6,1 \%)$. Berdasarkan hasil penelitian, status gizi secara signifikan berhubungan dengan perkembangan motorik anak dengan nilai $p=$ 0,04 artinya ada hubungan yang bermakna antara status gizi dengan perkembangan motorik kasar anak umur 1-3 tahun di posyandu Bunga Cengkeh Desa Puncak Harapan.

Adanya hubungan antara status gizi dengan perkembangan motorik dikarenakan salah satu faktor yang mempengaruhi motorik kasar adalah status gizi. Dengan status gizi yang baik, maka perkembangan motorik akan sesuai dengan umur batita. Anak-anak dengan status gizi kurang menyebabkan perkembangan motorik yang tidak sesuai disebabkan karena penurunan jumlah dan ukuran sel otak. Kemampuan system saraf pada otak untuk membuat dan melepaskan neurotransmitter tergantung pada konsentrasi zat gizi tertentu dalam darah yang diperoleh dari komposisi makanan yang dikonsumsi. ${ }^{10}$

Berdasarkan hasil penelitian status gizi batita di posyandu Bunga Cengkeh desa Puncak Harapan yang paling tinggi yaitu status gizi normal. Hal ini disebabkan karena orang tua batita sudah mampu memberikan makanan pendamping yang seimbang antara kebutuhan dan asupan nutrisi batita seperti bubur yang dibuat sendiri dengan campuran bahan makanan yang mengandung vitamin, protein, kalsium yang baik untuk perkembangan dan pertumbuhan batita. Selain itu ibu juga mampu memberikan makanan yang bervariasi kepada batita yang tidak menyukai beberapa makanan seperti sayur, ikan atau makanan lainnya dengan memberikan telur dadar yang dicampur dengan kacang panjang atau kol. Dengan penyajian seperti itu anak seolah-olah tidak memakan sayur secara langsung, karena rasa telur lebih dominan dinikmati anak. Makanan memegang peranan penting dalam tumbuh kembang anak.

Masa anak di bawah lima tahun merupakan periode penting dalam tumbuh kembang anak karena pertumbuhan dasar yang berlangsung pada masa balita akan mempengaruhi dan menentukan perkembangan anak selanjutnya. Dalam pertumbuhan dan perkembangan anak memerlukan zat gizi agar proses pertumbuhan dan perkembangan berjalan dengan baik. Zat-zat yang dikonsumsi balita akan berpengaruh pada status gizi balita. Perbedaan status gizi balita akan memberikan pengaruh yang berbeda pada setiap perkembangan anak, apabila gizi seimbang yang dikonsumsi tidak terpenuhi, pencapaian pertumbuhan dan perkembangan anak terutama perkembangan motorik yang baik akan terhambat.

Hasil penelitian ini sejalan dengan hasil penelitian Lindawati (2010) didapatkan bahwa tingkat perkembangan motorik anak dengan status gizi kurang tidak sesuai terjadi pada $66,7 \%$ responden, sedangkan tingkat 
perkembangan motorik anak dengan status gizi normal tidak sesuai hanya terjadi pada $32,8 \%$ responden. Dengan hasil hitung 0,005 dan $p$ value 0,01 artinya ada hubungan antara status gizi dengan perkembangan motorik kasar. ${ }^{11}$

Namun hasil penelitian ini bertentangan dengan hasil penelitian Gunawan,dkk (2010) dengan jumlah subjek 321 anak usia 6 sampai 24 bulan dan yang memenuhi criteria inklusi 308 anak, terdiri dari 164 laki-laki $(53,2 \%)$ dan 114 perempuan (46,8\%). Anak yang mengalami perkembangan normal 278 anak $(90,22 \%)$ dan meragukan 30 anak $(9,78 \%)$. Sedangkan status gizi normal 277 anak $(89,9 \%)$ dan kurus 31 anak $(10,10 \%)$. Dari 31 anak dengan status gizi kurang, diantara 2 anak lainnya mengalami perkembangan meragukan mempunyai status gizi normal. Tidak terdapat hubungan antara status gizi dengan perkembangan motorik $(p=$ $0,394){ }^{12}$

Kelebihan dari penelitian ini adalah jumlah responden yang sedikit sehingga memudahkan pengamatan langsung tentang perkembangan motorik batita, pertanyaan yang sejalan dengan peneltian dan mudah dipahami oleh responden, tempat tinggal responden

\section{DAFTAR PUSTAKA}

1. Sutrisno YM. 2014. Hubungan Status Gizi dengan Perkembangan Motorik Kasar anak usia 6-24 bulan di Posyandu desa Pari Kecamatan Mandala kabupaten yang tidak jauh dari tempat tinggal peneliti, dan bahasa yang digunakan saat penelitian yang mengikuti kultur responden.

\section{KESIMPULAN DAN SARAN}

Berdasarkan hasil penelitian yang dilakukan di posyandu Bunga Cengkeh desa Puncak Harapan kecamatan Maiwa kabupaten Enrekang pada tanggal 25 Mei-26 Mei 2018 dapat disimpulkan bahwa ada hubungan antara status gizi dengan perkembangan motorik kasar anak umur 1-3 tahun di posyandu Bunga Cengkeh desa Puncak Harapan Kecamatan Maiwa. Berdasarkan hasil kesimpulan, disarankan agar orang tua dapat tetap memperhatikan asupan nutrisi untuk memperbaiki status gizi batita sehingga perkembangan motoriknya akan sesuai dengan umur meskipun sudah beranjak ke tingkatan umur berikutnya karena salah satu faktor yang mempengaruhi perkembangan motorik kasar adalah status gizi anak. Selanjutnya bagi pihak kader posyandu disarankan agar memberikan pemahaman mengenai pentingnya status gizi batita dan mendampingi orang tua batita saat dilakukan penyuluhan oleh pihak puskesmas setempat

Pandeglang provinsi Banten Tahun 2014.[Skripsi]. Universitas Islam Negeri Syarif Hidayatullah Jakarta.

2. Dudley L dan Vashe T. 2010. Vision Therapy and Psyhososial Carrelates of 
Global Developmental Delay, Journal of Behavioral Optometry. 21(2): 39-45. www.oepf.org/jbo/journals/212\%20Dudley.pdf. [Diakses tanggal 11 Juli 2018].

3. Maryanti. 2011. Buku Ajar Neonatus, Bayi \& Balita. Prenada Media Group: Jakarta

4. Hanifakh HS. 2014. Upaya Meningkatkan Kemampuan Keseimbangan Tubuh Melalui Metode Bermain Halang Rintang Anak Kelompok B Belimbing Mulya Desa Onje Kecamatan Mbrebet Kabupaten Purbalingga. [Skripsi]. Universitas Muhammadiyah Purwokerto.

5. Desmika WS. dkk. Hubungan Antara Status Gizi Dengan Perkembangan Motorik Kasar Anak Usia 1 - 5 Tahun Di Posyandu Buah Hati Ketelan Banjarsari Surakarta : KTI. 2012. KTI

6. [RISKESDAS] Riset Kesehatan Dasar 2013. Badan Penelitian dan Pengembangan Kesehatan Departemen Kesehatan RI 2008. Hal. 209

7. Maryuni. dkk. 2016. Hubungan antara Perkembangan Motorik Anak Usia 3 - 5 Tahun dengan Status Gizi (Tb/U) Berdasarkan Tingkat Pendidikan Ibu.
[Jurnal Gizi] volume (2):6 https://www.google.co.id/search?q=Perke mbangan+Motorik+Kasar+Anak

+ Usia+3-

5+Tahun+dengan+Status+Gizi+(Tb/U)+B erdasarkan

Tingkat+Pendidikan+Ibu\&client=ucwebmini-b\&channel=lb[Diakses pada 15 Maret 2018]

8. Data Pemantauan Status Gizi Balita di Puskesmas Maiwa, 2017.

9. Undang-Undang Republik Indonesia No.20 Tahun 2003 tentang Sistem Pendidikan Nasional

10. Choirunnisa. dkk. 2013. Hubungan antara Status Gizi dengan Perkembangan Motorik Kasar Anak Balita di RSUD Tugurejo Semarang tahun 2013. STIKES Telogorejo Semarang.

11. Lindawati. 2013. Faktor-faktor yang Berhubungan dengan Perkembangan Motorik Anak Usia Pra Sekolah. Jurnal. Jakarta : Jurusan Keperawatan Poltekkes Kemenkes Jakarta I.

12. Gunawan. dkk. 2010. Hubungan Status Gizi dengan Perkembangan Motorik Kasar anak usia 1-3 tahun. Universitas Padjajaran. 


\section{LAMPIRAN}

Tabel 1. Distribusi Ibu Responden Berdasarkan Tingkat Pendidikan, Pekerjaan dan Umur di Posyandu Bunga Cengkeh desa Puncak Harapan

\begin{tabular}{lrr}
\hline \multicolumn{1}{c}{ Karakteristik } & n & \% \\
\hline Tingkat Pendidikan Ibu & & 21,2 \\
SD & 7 & 42,4 \\
SMP & 14 & 21,2 \\
SMA & 7 & 15,2 \\
Sarjana & 5 & \\
Pekerjaan & & 6,1 \\
Honorer & 2 & 87,9 \\
IRT & 29 & 6,1 \\
Petani & 2 & 24,2 \\
Umur (tahun) & & 54,5 \\
22-26 & 8 & 9,1 \\
27-31 & 18 & 12,1 \\
32-36 & 3 & $\mathbf{1 0 0 , 0}$ \\
\hline 36 & 4 & \\
\hline Total & $\mathbf{3 3}$ & \\
\hline
\end{tabular}

Sumber: Data Primer Tahun 2018

Tabel 2. Distribusi Karakteristik Responden Berdasarkan Jenis Kelamin, Umur dan Jumlah Saudara di Posyandu Bunga Cengkeh desa Puncak Harapan

\begin{tabular}{ccc}
\hline Karakteristik & $\mathbf{n}$ & \% \\
\hline Jenis Kelamin & & \\
Laki-laki & 15 & 45,5 \\
Perempuan & 18 & 54,5 \\
\hline Umur (tahun) & & 30,3 \\
1 & 10 & 60,6 \\
2 & 20 & 9,1 \\
3 & 3 & 30,3 \\
\hline Jumlah Saudara & 10 & 36,4 \\
1 & 12 & 24,2 \\
2 & 8 & 6,1 \\
3 & 2 & 3,0 \\
\hline 5 & 1 & $\mathbf{1 0 0 , 0}$ \\
\hline Total & $\mathbf{3 3}$ & \\
\hline
\end{tabular}

Sumber: Data Primer Tahun 2018 
Tabel 3. Distribusi Responden Berdasarkan Status Gizi di Posyandu Bunga Cengkeh Desa Puncak Harapan

\begin{tabular}{ccc}
\hline Status Gizi & $\mathrm{n}$ & $\%$ \\
\hline Gizi Kurang & 7 & 21,2 \\
Gizi Normal & 26 & 78,8 \\
\hline Total & 33 & 100,0 \\
\hline
\end{tabular}

Sumber : Data Primer Tahun 2018

Tabel 4. Distribusi Responden Berdasarkan Perkembangan Motorik Kasar di Posyandu Bunga Cengkeh Desa Puncak Harapan

\begin{tabular}{ccc}
\hline Perkembangan motorik & $\mathrm{n}$ & $\%$ \\
\hline Sesuai & 31 & 93,9 \\
Tidak sesuai & 2 & 6,1 \\
\hline Total & 33 & 100,0 \\
\hline
\end{tabular}

Sumber : Data Primer Tahun 2018

Tabel 5. Distrbusi Hubungan Status Gizi dengan Perkembangan Motorik Kasar Anak Umur 1-3 Tahun di Posyandu Bunga Cengkeh Desa Puncak Harapan

\begin{tabular}{|c|c|c|c|c|c|c|c|}
\hline \multirow[b]{3}{*}{ Status Gizi } & \multicolumn{4}{|c|}{ Perkembangan Motorik Kasar } & \multirow{2}{*}{\multicolumn{2}{|c|}{ Total }} & \multirow[b]{3}{*}{$P$} \\
\hline & \multicolumn{2}{|c|}{ Sesuai } & \multicolumn{2}{|c|}{ Tidak Sesuai } & & & \\
\hline & $\mathrm{n}$ & $\%$ & $\mathrm{n}$ & $\%$ & $\mathrm{n}$ & $\%$ & \\
\hline Normal & 26 & 100,0 & 0 & 0 & 26 & 100,0 & \\
\hline Kurang & 5 & 71,4 & 2 & 6,1 & 7 & 100,0 & 0,04 \\
\hline Total & 31 & 93.9 & 2 & 6,1 & 33 & 100,0 & \\
\hline
\end{tabular}

Sumber : Data Primer Tahun 2018 